
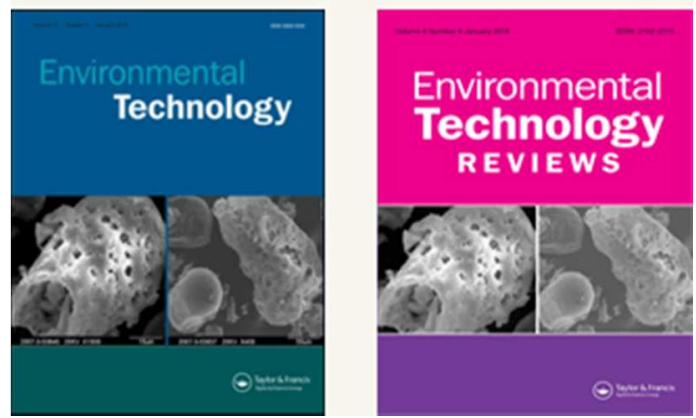

\title{
Recruitment of cyanobacteria from the sediments in the eutrophic Shanzi Reservoir
}

\begin{tabular}{|r|l|}
\hline Journal: & Environmental Technology \\
\hline Manuscript ID: & TENT-TENT-2015-0220.R1 \\
\hline Manuscript Type: & Original Article \\
\hline Date Submitted by the Author: & n/a \\
\hline Complete List of Authors: & $\begin{array}{l}\text { Su, Yuping; Fujian Normal University, } \\
\text { Zhang, Dayi; Lancaster University, Lancaster Environment Centre }\end{array}$ \\
\hline Keywords: & eutrophication, Microcystis, Oscillatoria, recruitment, quantitative PCR \\
\hline & \\
\hline
\end{tabular}

SCHOLARONE ${ }^{\prime \prime}$

Manuscripts 


\title{
Recruitment of cyanobacteria from the sediments in the eutrophic Shanzi Reservoir
}

\author{
Yuping $\mathrm{Su}^{1,2}$, Xuejing You ${ }^{1}$, Hui Lin ${ }^{1}$, Huiru Zhuang ${ }^{1}$, Yuan $\mathrm{Weng}^{1}$, Dayi Zhang ${ }^{1,2,{ }^{*}}$ \\ 1. Environmental Science and Engineering College, Fujian Normal University, \\ Fuzhou, China PR, 350007
}

2. Lancaster Environment Centre, Lancaster University, Lancaster, UK, LA1 4YW

\author{
Correspondence to: Dayi Zhang \\ Lancaster Environment Centre, Lancaster University \\ Lancaster, UK, LA1 4YW \\ E-mail: d.zhang@lancaster.ac.uk
}




\begin{abstract}
This study investigated the impacts of four environmental factors on the recruitment of cyanobacteria from the bottom sediments in the eutrophic Shanzi Reservoir. Temperature and light were identified as the key determinants for the recruitment of Microcystis and Oscillatoria. Cyanobacteria became dominant at higher temperature $\left(20^{\circ} \mathrm{C}\right)$ and light intensity $(2,000 \mathrm{~lx})$, and Microcystis and Oscillatoria were the major species. Detailed recruitment simulation undertaken with respective gradient of temperature and light suggested that both Microcystis and Oscillatoria are temperature sensitive, and their critical temperature point was $10^{\circ} \mathrm{C}$. However, distinct light impacts were observed only on Microcystis. The recruitment of Oscillatoria was light independent, whereas Microcystis had positive relationship with light intensity. Physical disturbance promoted Microcystis recruitment and also affected the structure of recruited cyanobacterial community the water-sediment interaction, based on quantitative polymerase chain reaction (qPCR) and phylogenetic analysis.
\end{abstract}

\title{
Keywords
}

eutrophication, Microcystis, Oscillatoria, sediment, recruitment, quantitative PCR 


\section{Introduction}

China has recently suffered from not only shortage of water resources to support the growing number of cities, but also severe water contamination [1]. With the rapid economic development and associated human activities, the contaminants from industry, agriculture and domestic wastes have consequently resulted in the deterioration of water quality in reservoirs. It is reported that one third of Chinese important reservoirs are or are becoming eutrophic [1]. As the consequence of water eutrophication, cyanobacteria blooms, particularly the toxigenic cyanobacteria like Microcystis, directly threaten the drinking water safety [2].

The growth and formation of cyanobacterial blooms were suggested to have four stages, including featuring dormancy, recovery, increasing biomass and floating upward to form water blooms [3]. Cyanobacteria recruitment has been regarded as a process where benthic overwintering cyanobacteria migrate to the pelagic phase and renew growth under suitable conditions [4]. Increasing more research has attempted to reveal the key factors affecting the recruitment of cyanobacteria. Those environmental parameters, besides nutrients as nitrogen and phosphate, showed significant impacts on the recruitment and population fluctuation of cyanobacteria, as well as the structure and functions of microbial community [5]. More interestingly, cyanobacteria might be dominant but inert at the water-sediment interface when environmental conditions are harsh for recruitment like low temperature or light limitation, until rapidly growing under suitable conditions, a so-called rejuvenation phase [6]. It is therefore important to uncover the factors affecting the accumulation and distribution of cyanobacteria at the water-sediment interface, and the determinants contributing to the recruitment process.

Since the exposure to microcystin was highly associated with primary liver cancer in some areas of China [7], the microcystin producing cyanobacterial genus, Microcystis, has drawn increasingly more attention [8]. Some environmental factors affected Microcystis recruitment in natural environment, including temperature, light, nutrients, dissolved oxygen, physical resuspension and bioturbance [9, 10, 11, 12]. Microcystis 
was reported to become active in sediments when the temperature of deep lakes reached 7 to $8{ }^{\circ} \mathrm{C}[13]$, and their growth rate increased significantly at $15^{\circ} \mathrm{C}$. On the contrary, though the growth rate of Microcystis was sensitive to light intensity, its recruitment process is not light-sensitive $[12,14]$. The low level of photosynthesizing efficiency and electron transfer rate can only restrict their growth rate. However, the key restricted factors vary in lakes from different regions, and it is therefore important to uncover the key environmental determinants in specific lake conditions for practical water quality management.

This research introduced orthogonal recruitment experiments to address the determinants affecting the cyanobacteria recruitment in the sediments of Shanzi Reservoir (China), which is a classic subtropical small reservoir. Four environmental factors, temperature, light intensity, physical disturbance and nutrients, were experimentally manipulated to evaluate the contribution of sediment to the recruitment process of planktonic populations in this eutrophic reservoir $[12,14,15$, 16]. Detailed study of quantitative PCR and microbial community at water-sediment interface also provided the in situ dynamic information on Microcystis recruitment from sediment into the water body in Shanzi Reservoir.

\section{Experimental details}

\subsection{Sampling site}

Shanzi Reservoir was built in 1992 and is one of the important drinking water resources of Fuzhou district, Fujian Province, China (Figure 1). It is located within the catchment of Aojiang River, which is the sixth largest river in Fujian Province, 137 $\mathrm{km}$ length and with a $2,655 \mathrm{~km}^{2}$ watershed. Shanzi Reservoir has regulation storage of $1.06 \times 10^{8} \mathrm{~m}^{3}$ with a surface area of $6.639 \mathrm{~km}^{2}$ and average depth of $25 \mathrm{~m}$. The upriver catchment area of Shanzi Reservoir is $1,646 \mathrm{~km}^{2}$ with an annual average depth runoff of $1.857 \times 10^{9} \mathrm{~m}^{3}$ respectively [17]. With integrated usages of irrigation, electricity generation, water supply and flood control, Shanzi Reservoir has experienced severe eutrophication. The algal blooms occur every year from May to October, and the 
conditions and extent of its outbreak in late spring determine the level and scale of algal bloom in the following months [17]. The dominant species are cyanobacteria, especially Microcystis, with strong impacts on water quality [2].

\subsection{Samples collection and analysis}

During the algal bloom period (May to October), numerous recruited cyanobacteria could be found in both sediment and water samples and their existence affected the evaluation on environmental factors affecting cyanobacterial recruitment. Thus, the sediment and water samples were taken in Shanzi Reservoir $\left(26^{\circ} 20^{\prime} 22^{\prime \prime} \mathrm{N}\right.$ and $119^{\circ} 19^{\prime} 48^{\prime \prime E}, 10 \mathrm{~m}$ depth) in November 2010. A total $2.0 \mathrm{~L}$ of water-sediment interface water was collected within $20 \mathrm{~cm}$ distance above the sediment. Subsequently, the sixteen sediment cores were collected from $0 \mathrm{~cm}$ to $10 \mathrm{~cm}$ in the sediment by the Kajak sediment corer $(6 \mathrm{~cm}$ in diameter) for further chemical and biological analysis (UWITECH, Mondsee, Austria). Both water and soil samples were stored in the plexiglass tubes (diameter $6 \mathrm{~cm}$ and height $25 \mathrm{~cm}$ ) at $4{ }^{\circ} \mathrm{C}$ for further recruitment experiment. The $1.0 \mathrm{~L}$ of water-sediment interface water was filtered by $0.45 \mu \mathrm{m}$ filter, (Millipore, USA) to removal residual cyanobacteria and suspended solids. Filtered water $\mathrm{pH}$ value (6.5-7.0) was measured by $\mathrm{pHS}-3 \mathrm{C}$ series $\mathrm{pH}$ Meter (Shanghai REX Instrument Factory, China). The total nitrogen (TN) in water sample was directly determined by $\mathrm{K}_{2} \mathrm{~S}_{2} \mathrm{O}_{8}$ spectrophotometric method, and the total phosphate (TP) was measured by phosphatic molybdenum spectrophotometry [18]. For sediment samples, TN and TP were determined by vario EL III Element Analyzer (Elementar, Germany) and molybdenum blue/ascorbic acid method [19].

\section{$2.3 \quad$ Recruitment experiment}

The orthogonal experiments addressed the impacts of light, temperature, nutrients and disturbance on cyanobacterial recruitment, the different treatments of which were shown in Table 1. Briefly, $15 \mathrm{~g}$ of sediment samples was transferred into a cylindrical glass column for recruitment simulation. In accordance with the annual spring temperature variation of Shanzi Reservoir $\left(10^{\circ} \mathrm{C}\right.$ to $\left.20^{\circ} \mathrm{C}\right)$, the two temperature levels in recruitment experiment were $10^{\circ} \mathrm{C}$ and $20^{\circ} \mathrm{C}$, representing early and late spring 
respectively. The two light intensity conditions included the high light treatment of 2,000 lx and low light treatment $50 \mathrm{~lx}$. The dark condition was achieved by covering the light source with kraft paper, and a $12 \mathrm{~h}: 12 \mathrm{~h}$ light-dark-cycle was used to simulate natural conditions. Two recruitment medium $(25 \mathrm{~mL})$, filtered water-sediment interface water or BG11 medium, were furnished with the sediment to investigate the impacts of nutrients. The BG11 medium contained $17.6 \mathrm{mM} \mathrm{NaNO}$, $0.22 \mathrm{mM} \mathrm{K}_{2} \mathrm{HPO}_{4}, 0.3 \mathrm{mM} \mathrm{MgSO}, 0.2 \mathrm{mM} \mathrm{CaCl}_{2}, 0.03 \mathrm{mM}$ citric acid, $0.02 \mathrm{mM}$ ferric ammonium citrate and $0.002 \mathrm{mM} \mathrm{Na} 2 \mathrm{EDTA}, 0.18 \mathrm{mM} \mathrm{Na}_{2} \mathrm{CO}_{3}$ and $1 \mathrm{~mL} \mathrm{~L}^{-1}$ BG11 trace metal solution [20]. The $\mathrm{pH}$ value of BG11 medium was adjusted at 6.5-7.0 by adding $0.1 \mathrm{M} \mathrm{NaOH}$ or $\mathrm{HCl}$. Physical disturbance was simulated with a shaker, which provided $60 \mathrm{rpm}$ vertical shaking for 30 minutes at 09:00 h, 15:00 h and 21:00 h each day, simulating the sluice activities in the field. Each treatment was set up with three replicates and cultivated in PGXX-350B (Fuma, China) and PGX-160C (Fuma, China) intelligent incubator. From preliminary test, significant cyanobacterial recruitment was observed within 4 days from sediments [2], and the recruitment experiment in this study therefore was carried out for 6 days. The recruitment experiments were carried out in two separate time periods as biological replicates.

To address the impacts of temperature and light on the recruited algal community structure, further experiment was set up under six temperatures $(6,8,10,12,14$ and $\left.16^{\circ} \mathrm{C}\right)$ and two light conditions $(2,000$ and $50 \mathrm{~lx})$. The $200 \mathrm{~mL}$ filtered water-sediment interface water was transferred into PGX-160C intelligent biochemical incubator to cover the six sediment cores. After recruitment for 6 days, the $200 \mathrm{~mL}$ of the supernatant was subsequently collected for further algae counting and molecular biological analysis.

\subsection{Cyanobacterial community analysis by algae counting}

The algal species in water solution were identified with the binocular biological microscope (Motic, BM-1000, Guangzhou) [21]. Briefly, $300 \mu \mathrm{L}$ Lugols iodine solution was added into $20 \mathrm{~mL}$ water sample, concentrated by centrifugation to the final volume of $100 \mu \mathrm{L}$. The $0.1 \mathrm{~mL}$ counting chamber $(20 \mathrm{~mm} \times 20 \mathrm{~mm})$ was utilized 
for microalgae identification and counting, and three replicates were applied. All the samples were measured at $4^{\circ} \mathrm{C}$ under dark condition, and the microalgae counts were converted to the cells per unit (cells/mL) by the following equation.

$$
N=\left(\frac{A}{A_{0}} \times \frac{1}{V}\right) \times n
$$

Here, $N$ refers to microalgae counts per millilitre water sample (cells $\mathrm{mL}^{-1}$ ). $A$ represents the area of counting chamber $\left(\mathrm{mm}^{2}\right)$, and $A_{0}$ was the counting area $\left(\mathrm{mm}^{2}\right)$. $V$ is the volume of counting chamber $(0.1 \mathrm{~mL})$, and $n$ refers to the number of microalgae within the counting area (cells). For multicellular filamentous Oscillatoria, the number was counted by individual cells under microscope.

To determine the microalgae counts in sediment samples, the $1.0 \mathrm{~g}$ of fresh sliced samples from the water-sediment interface were mixed well with $100 \mathrm{~mL}$ deionized water in clean breakers. The upper $30 \mathrm{~mL}$ suspension was taken and added with 450 $\mu \mathrm{L}$ Lugols iodine solution and $1.27 \mathrm{~mL}$ formaldehyde solution (final concentration of $4 \%, \mathrm{~V} / \mathrm{V})$. The algal counting and calculation followed the same instruction as described in water sample analysis.

\subsection{PCR amplification for specific gene fragments}

Genomic DNA of sediment samples was extracted with CTAB methods as described previously [22]. All the primers applied in this research were designed in accordance with previous research and synthesized by VWR International LLC, as listed in Table 2. All the PCR programs were undertaken in C1000 Thermal Cycler (BioRad, USA), and the reaction system $(50 \mu \mathrm{L})$ contains $2.5 \mu \mathrm{L}$ of each primer, $0.5 \mu \mathrm{L}$ DreamTaq DNA polymerase (Thermo Scientific, USA), $5 \mu \mathrm{L}$ DreamTaq green buffer (Thermo Scientific, USA), $1 \mu \mathrm{L}$ dNTPs $(5 \mathrm{mM}), 1 \mu \mathrm{L}$ DNA template and $41 \mu \mathrm{L}$ molecular water (Sigma Aldrich, USA). Three groups of primers were designed to address the quantification of microcystin synthetase genes $(m c y A$ and $m c y B)$, bacterial $16 \mathrm{~S}$ rRNA and cyanobacterial 16S rRNA. For mcyA microcystin synthetase genes (mcyA_f and mcyA_r), the PCR program consisted of an initial stage of $5 \mathrm{~min}$ at $94{ }^{\circ} \mathrm{C}$, followed by 40 cycles of $10 \mathrm{~s}$ at $94^{\circ} \mathrm{C}, 20 \mathrm{~s}$ at $50^{\circ} \mathrm{C}$ and $60 \mathrm{~s}$ at $72^{\circ} \mathrm{C}$, and the final extension at 
$72^{\circ} \mathrm{C}$ for $5 \mathrm{~min}$ [23]. For the Microcystis-specific $16 \mathrm{~S}$ rRNA and $m c y B$ microcystin synthetase genes, Nested PCR was applied with respective primers [24]. For the first generation PCR, including 16S_f1/16S_r1 for Microcystis-specific 16S rRNA and MCY_f1/MCY_r1 for $m c y B$ microcystin synthetase genes, the initial denaturation is $30 \mathrm{~s}$ at $94^{\circ} \mathrm{C}$, followed by 45 cycles of $30 \mathrm{~s}$ at $94^{\circ} \mathrm{C}, 45 \mathrm{~s}$ at $57^{\circ} \mathrm{C}$ and $60 \mathrm{~s}$ at $72^{\circ} \mathrm{C}$, with a final extension of $10 \mathrm{~min}$ at $72^{\circ} \mathrm{C}$ [25]. For the second generation for Microcystis-specific 16S rRNA (16S_f2/16S_r1) and mcyB microcystin synthetase genes (MCY_fl/MCY_r2), the initial denaturation was $30 \mathrm{~s}$ at $94^{\circ} \mathrm{C}$, followed by 40 cycles of $30 \mathrm{~s}$ at $94^{\circ} \mathrm{C}, 45 \mathrm{~s}$ at $57^{\circ} \mathrm{C}$ and $60 \mathrm{~s}$ at $72^{\circ} \mathrm{C}$, with a final extension of $10 \mathrm{~min}$ at $72{ }^{\circ} \mathrm{C}$ [25]. For the cyanobacteria-specific $16 \mathrm{~S}$ rRNA genes (209f and 409r), the initial denaturation was $94^{\circ} \mathrm{C}$ for $4 \mathrm{~min}$, followed by 40 cycles of $94^{\circ} \mathrm{C}$ for $20 \mathrm{~s}, 50^{\circ} \mathrm{C}$ for $30 \mathrm{~s}$ and $72^{\circ} \mathrm{C}$ for $120 \mathrm{~s}$, with the final extension at $72^{\circ} \mathrm{C}$ for $5 \min$ [26]. The PCR program for total bacteria $16 \mathrm{~S}$ rRNA genes (63f/1387r and 519f/907r) consisted of an initial denaturation of $4 \mathrm{~min}$ at $95^{\circ} \mathrm{C}$, followed by 40 cycles of $30 \mathrm{~s}$ at $95^{\circ} \mathrm{C}, 60 \mathrm{~s}$ at $58^{\circ} \mathrm{C}$ and $120 \mathrm{~s}$ at $72^{\circ} \mathrm{C}$, and the final extension at $72^{\circ} \mathrm{C}$ for $5 \mathrm{~min}[27,28]$. The PCR products of $m c y A$ microcystin synthetase fragments were ligated into the pGEM-T vector (Promega, USA), transferred into E. coli JM109 competent cells by heat shock, and then selected on LB agar with $300 \mathrm{mg} / \mathrm{L}$ ampicillin as the antibiotic pressure. The plasmids with specific $m c y A$ fragment of the positive clones were extracted and sent for sequence.

\subsection{Quantitative PCR}

Quantitative PCR was applied to quantify the copies of Microcystis-specific 16S rRNA and $m c y B$ microcystin synthetase genes in sediment samples with CFX96 Real-Time PCR Detection System (BioRad, USA). The reaction system $(10 \mu \mathrm{L})$ consisted of $5 \mu \mathrm{L}$ iTAQ SYBR-green supermix (BioRad, USA), $1.0 \mu \mathrm{L}$ of each primer, 1.0 $\mu \mathrm{L}$ DNA template and $2.0 \mu \mathrm{L}$ molecular water. The program of each reaction was identical to that described above for each pair of primers, with additional melting curve detection from $65{ }^{\circ} \mathrm{C}$ to $95{ }^{\circ} \mathrm{C}$ at $0.5{ }^{\circ} \mathrm{C}$ intervals. All the amplified DNA fragments were purified with the Gel Extraction Kit (QIAGEN, USA). The DNA 
fragments were subsequently cloned into the pGEM ${ }^{\circledR}-\mathrm{T}$ vector (Promega, USA) following the manufacturer's instructions. Plasmid DNA was then extracted and purified with Minipreps Kit (Promega, USA) and the inserts were confirmed by PCR with the respective program. The DNA concentration was determined with Quant-iTтм PicoGreen ${ }^{\circledR}$ dsDNA Reagent and Kits (Invitrogen, USA) with $480 \mathrm{~nm}$ excitation and $520 \mathrm{~nm}$ detection wavelength, by Synergy 2 plate reader (BioTek, USA). The plasmid copy number of each DNA insert was determined by the amount and molecular weight of the targeting double-stranded plasmid [22]. All the plasmids were diluted in the series of $3 \times 10^{8}, 3 \times 10^{7}, 3 \times 10^{6}, 3 \times 10^{5}, 3 \times 10^{4}, 3 \times 10^{3}, 3 \times 10^{2}, 3 \times 10^{1}$ and $3 \times 10^{0}$ copies for each reaction, quantified together with the targeting environmental samples in the same qPCR program to obtain the linear standard curve, as illustrated in Table 3 and Figure S1.

\subsection{Data analysis}

SPSS package (version 11.0) was used for statistical analysis by ANOVA analysis of all the variance. All the data were the values are the means of data from three independent replicates and the $p$-value $<0.05$ was considered as statistical significance. The phylogenetic tree of $m c y A$ genes (Shanzi S1, Shanzi S2 and Shanzi S3) from Shanzi Reservoir was calculated and drawn in MEGA 4.0 (http://www.megasoftware.net/mega4/mega.html), and compared with 20 known $m c y A$ genes of Microcystis sp. from NCBI database (http://www.ncbi.nlm.nih.gov/).

\section{Results and discussion}

\subsection{Impacts of temperature and light on cyanobacteria recruitment}

The results of recruitment experiments (Table 1) showed that Microcystis and Oscillatoria were the two primary recruited cyanobacteria from the sediments. Of all the factors tested in this study, the determinants regulating the recruitment of Microcystis were identified as temperature, light and physical disturbance from ANOVA analysis (Table S1). Under low temperature $\left(10^{\circ} \mathrm{C}\right)$ and light $(50 \mathrm{~lx})$ conditions, the population of Microcystis was only $252 \pm 15$ cells $\mathrm{mL}^{-1}$, whereas they 
increased 40 times $\left(9,934 \pm 397\right.$ cells $\left.\mathrm{mL}^{-1}\right)$ at $20^{\circ} \mathrm{C}$ and $2,000 \mathrm{~lx}$ after 6 days. More precisely from the analysis of variance (Table 1), Microcystis recruitment was stimulated by the temperature (averagely 1,321 cells $\mathrm{mL}^{-1}$ at $10^{\circ} \mathrm{C}$ and 5,941 cells $\mathrm{mL}^{-1}$ at $20^{\circ} \mathrm{C}$ ) and light (averagely 1,950 cells $\mathrm{mL}^{-1}$ with $50 \mathrm{~lx}$ and 5,312 cells $\mathrm{mL}^{-1}$ with 2,000 lx) respectively. As for the impacts of physical disturbance, Microcystis count was higher in disturbance treatments $\left(3,271\right.$ cells $\left.\mathrm{mL}^{-1}\right)$ than in no disturbance treatments $\left(630\right.$ cells $\left.\mathrm{mL}^{-1}\right)$. The possible reason was the enhancement of nutrients distribution and cell-mineral interaction to accelerate recruitment process [29, 30]. The similar Microcystis count $\left(3,742\right.$ cells $\mathrm{mL}^{-1}$ in raw water and 3,520 cells $\mathrm{mL}^{-1}$ in BG11 medium) showed limited effect of nutrients in this study. The optimal conditions for Microcystis recruitment were therefore identified as $20^{\circ} \mathrm{C}$ and $2,000 \mathrm{~lx}$ with physical disturbance. The recruitment of Oscillatoria was significantly slower than Microcystis (Table S2), and the average populations were $1325 \pm 68$ cells $\mathrm{mL}^{-1}$ under $20^{\circ} \mathrm{C}$ and $2,000 \mathrm{~lx}$ condition (Table 1 ). The analysis of variance only illustrated one key factor, temperature, affecting Oscillatoria recruitment (averagely 334 cells $\mathrm{mL}^{-1}$ at $10^{\circ} \mathrm{C}$ and 1,457 cells $\mathrm{mL}^{-1}$ at $20^{\circ} \mathrm{C}$ ).

Cultivated in different temperature conditions, more evidence was found on the impacts of temperature and light on the recruitment rate of Microcystis and Oscillatoria (Figure 2). A significant lag phase was observed for both strains at $8^{\circ} \mathrm{C}$. The positive relationship was found between the temperature and Microcystis/Oscillatoria from $10^{\circ} \mathrm{C}$ to $16^{\circ} \mathrm{C}$, and the correlation was similar to previous investigation on the impacts of temperature on cyanobacteria growth from $20^{\circ} \mathrm{C}$ to $35^{\circ} \mathrm{C}$ [31]. The results indicated that temperature is a sensitive factor for Microcystis/Oscillatoria in Shanzi Reservoir under late spring conditions. There was no significant difference for Oscillatoria recruitment under different light conditions (Figure 2b).

The results were similar to previous research that Microcystis was sensible to the light for recruitment [32] and Oscillatoria were less light sensitive [33]. Given the interspecific competitive recruitment and the annual spring temperature in Shanzi Reservoir $\left(10^{\circ} \mathrm{C}\right.$ to $\left.20^{\circ} \mathrm{C}\right)$, it explained the dominancy of Microcystis, rather than 
Oscillatoria, in the blooms. Under this optimal condition [30], Microcystis became the dominant cyanobacterial species during the eutrophication in South China, previously reported to constitute $95 \%$ of the total cyanobacterial population in Taihu Lake [34]. It also explained that Microcystis was the dominant species in the sediments in winter while in the water suspension in summer [35].

\subsection{Cyanobacterial community structure at water-sediment interface}

From the microbial community analysis of original water and sediment samples, cyanobacteria and diatoms $(62.5 \%$ and $37.5 \%$ respectively $)$ were dominant at the water-sediment interface, whereas Chlorella were hardly found in water phase (less than $1 \%$ ) but mainly in the water body $(5.3 \%$, Figure $3 a)$. The cyanobacteria in the sediment microbial community decreased with the increasing light intensity as $2.7 \%$ and $5.4 \%$ for $2,000 \mathrm{~lx}$ and $50 \mathrm{~lx}$ treatments respectively (Figure $3 \mathrm{~b}$ and $3 \mathrm{c}$ ). No significant change was observed for diatom $(89.8 \%, 91.0 \%$ and $92.0 \%$ in original, 2,000 lx and $50 \mathrm{~lx}$ treatments, $p$-value $>0.05)$ and Chlorella $(5.3 \%, 3.6 \%$ and $5.3 \%$ in original, 2,000 lx and $50 \mathrm{~lx}$ treatments, $p$-value $>0.05$ ) profiles in sediment at different levels. At the water-sediment interface, high light treatment $(2,000 \mathrm{~lx})$ significantly improved cyanobacterial recruitment (from $62.5 \%$ to $71.4 \%$ ), whereas diatoms became dominant in low light treatment (50 lx, from 37.5\% to 64.0\%). No Chlorella recruitment was observed (less than $1 \%$ of the total population). From previous evidence, cyanobacteria had the chlorophyll and phycobiliprotein to utilize the light with wavelength from $500 \mathrm{~nm}$ to $600 \mathrm{~nm}$ [36], which is not valid for other algal species. Thus, the high efficiency of cyanobacterial photosynthesis activity contributed to its dominancy under high light conditions $[16,37,38]$. The intra-cellular carbohydrate of Oscillatoria possibly provided enough energy to recruit, as stated previously in Taihu Lake [36].

From the annual cycle of Microcystis $s p$. at the water-sediment interface, the low temperature and light intensity in winter therefore was not suitable condition for cyanobacteria recruitment. It consequently resulted in different community structure at the water-sediment interface and main water body. During the winter when the 
temperature in Shanzi Reservoir was estimated to be $10^{\circ} \mathrm{C}$, the Microcystis recruitment was inhibited in the water body [39] and Microcystis mainly existed in the sediment [35]. After carbohydrate accumulation in winter, Microcystis started the effective photosynthesis in late spring when the temperature is above $10^{\circ} \mathrm{C}$, further leading to their dominancy in water phase $[40,41,42]$. Compared with previous field simulation of sediment Microcystis recruitment in Dianchi Lake [43] and Hirosawa-no-ike Pond [44], the strong positive relationship between monthly temperature change and the concentration of Microcystis in water sample has suggested that temperature is the key environmental factor affecting Microcystis recruitment at the water-sediment interface.

Sediment disturbance had significant impacts on cyanobacteria recruitment in this study. The frequent water-sediment interface disturbance and mixture in shallow lake helped in forming complex community structure, promoting cell-cell or cell-mineral interaction to accelerate recruitment process $[29,30]$. Different from the key factors in other lakes with fewer depth [45], this study indicated the importance of microbial community in cyanobacterial recruitment and bloom formation in deep lake, instead of the weak historical and physical disturbance. The remarkable effects of physical disturbance on Microcystis and Oscillatoria in this work explained the better recruitment of cyanobacteria under disturbance, fitting well with physiological research on Microcystis recruitment [46, 47]. The aerobic environment created by physical disturbance benefited their resuscitation from the sediment into water body [48]. It was reported that the single vertical convection type of water temperature in Shanzi reservoir could form a stable thermal stratification from March to November [49]. The stratification disappearance from December to next February promoted vertical mixture, allowing the release of recruitment cyanobacteria from the sediment to the surface water, contributing to the planktonic populations and community succession.

No significant impact of nutrient was observed here due to minimal difference of TN/TP ratio between the BG11 medium and the bottom raw water. Bottom raw reservoir water contained $1.369 \mathrm{mg} \mathrm{L}^{-1}$ total nitrogen and $0.056 \mathrm{mg} \mathrm{L}^{-1}$ total 
phosphate, with the TN/TP ratio as 24.4, whereas BG11 selective culture medium contained $247 \mathrm{mg} \mathrm{L}^{-1}$ total nitrogen and $7.09 \mathrm{mg} / \mathrm{L}$ total phosphate, with the TN/TP ratio as 34.8. The average nitrogen concentration in the sediment of Shanzi Reservoir was around 3,000 $\mathrm{mg} \mathrm{kg}^{-1}$ with the major type of organic nitrogen, whereas the main phosphorus concentration consisted of active Fe/Al-P and organic phosphorus with the load of 600 to $1,000 \mathrm{mg} \mathrm{kg}^{-1}$. Obviously, the sediment of Shanzi Reservoir stored enough nutrients, especially the essential nitrogen sources [50], to support the recruitment of cyanobacteria, as the BG11 medium.

\subsection{Molecular quantification of cyanobacteria and toxic Microcystis}

Besides environmental physical factors, the cyanobacterial community structure is also affected by the existence of harmful Microcystis. As illustrated in Table 3, bacteria was the dominant species in the sediment with the $16 \mathrm{~S}$ copy number at $(4.4 \pm 0.03) \times 10^{9} \mathrm{~g}^{-1}$ dry sediment. The amount of cyanobacteria $16 \mathrm{~S}$ rRNA was of high level at $(3.6 \pm 0.31) \times 10^{6}$ copies $\mathrm{g}^{-1}$ dry sediment, which is equivalent to the cyanobacteria bloom occurred in Singapore [24,51]. With averagely 2 to 4 copies of 16S rRNA genes in cyanobacterial cells [52], the estimated cyanobacteria in sediment were $0.9 \times 10^{6}$ to $1.8 \times 10^{6}$ cells $\mathrm{g}^{-1}$ dry sediment. Microcystis had only one copy of $m c y A$ and $m c y B$ microcystin synthetase gene [53], indicating that the toxic cyanobacteria was around $1.2 \times 10^{5}$ to $2.1 \times 10^{5}$ cells $\mathrm{g}^{-1}$ dry sediment. The microcystin producing cyanobacteria therefore held $6.9 \%$ to $23.4 \%$ of total cyanobacteria in sediment. Compared with the numbers $\left(6.0 \times 10^{5}\right.$ cells $\mathrm{g}^{-1}$ dry sediment $)$ calculated with two $16 \mathrm{~S}$ rRNA copies in one Microcystis cell, $20.0 \%$ to $35.0 \%$ of total Microcystis sp. could produce toxic microcystin. The lower $m c y A$ copies in toxic cyanobacteria might be explained by the $m c y H A$ deletion in the proportion of inactive $m c y$ genotypes [54]. The results also indicated that the spatial and temporal diversity of microcystin producing cyanobacteria are highly associated with the environmental parameters in sediment samples [7], and the cyanobacteria with active mcyA and $m c y B$ genotypes were the dominant species in planktonic population, which has been proved in many cases $[22,26,54,55]$. 
Compared to quantitative analysis by flow cytometer [56], quantitative PCR identified and quantified Microcystis sp. at molecular biological level. Instead of the $16 \mathrm{~S}$ or $23 \mathrm{~S}$ rRNA analysis, the phylogenetic relationships of $m c y A$ genes (Figure 4) indicated three dominant toxic Microcystis sp. after recruitment from Shanzi Reservoir sediments. Shanzi S1 had high similarity (99\%) with M. aeruginosa FCY-28 and FCY-26 [57], suggesting its strong capability to produce microcystin toxins and compete with other nontoxic cyanobacteria in seasonal cyanobacteria bloom [58]. Shanzi S2 was similar (98\%) to M. botrys N-C 161/1 and M. viridis N-C 169/7, whereas Shanzi S3 had the high similarity (95\%) with M. aeruginosa SPC777 and M. aeruginosa PCC 7820. Previous morphological data support the results that Microcystis was the dominant cyanobacteria in the eutrophic Shanzi Reservoir [2], due to their inhibitory impacts on other species caused by microcystin toxins $[59,60]$. Besides, the diatom-cyanobacterial symbioses was also observed during the recruitment process (data not shown), indicating the contribution of diatom to the nitrogen fixation process of cyanobacteria could also promote Microcystis sp. recruitment [61]. The competition and symbiosis were recognized as another key factor affecting the recruitment of cyanobacteria [62].

\section{Conclusions}

This research has revealed that temperature, light and physical disturbance are the most important determinants regulating the cyanobacterial recruitment in early spring algal bloom in Shanzi Reservoir, whereas no significant impacts of nutrients were found due to its excess amount in the sediments. High temperature and light intensity stimulated cyanobacterial recruitment from the sediment. Oscillatoria recruitment was only sensitive to temperature, and the critical recruitment temperature was $10{ }^{\circ} \mathrm{C}$ for both Microcystis and Oscillatoria. Microcystis was also dominant during recruitment process, due to its utilization of specific light wavelength. While at the natural sediment and water interface, physical disturbance and nutrients were becoming more important for cyanobacterial recruitment. The water stratification in Shanzi Reservoir was interrupted in late spring, when vertical water mixture and 
water-sediment interface disruption significantly affected the composition and succession of the phytoplankton community. Both competition and symbiotic within the sediment community determined the structure of microbial and phytoplankton community, and the phylogenetic microcystin synthetase genes $(m c y A)$ of Microcystis $s p$. were suggested as the key indicator to explain the respective contribution of various environmental factors during the recruitment process.

\section{Acknowledgement}

The authors would like to thank financial support from the National Natural Science Foundation, China (41101060), the Natural Science Foundation of Fujian Province, China (2010J01250), and the Research Foundation of Education Bureau of Fujian Province, China (JA10085). 


\section{References}

[1] Han B, Liu Z. Tropical and sub-tropical reservoir limnology in China: Theory and practice: Springer; 2012.

[2] Su Y, Chen N, Lin W, Liang X. Analysis of phytoplankton characteristic and eutrophication in Shanzi Reservoir, Fujian Province. Journal of Subtropical Resources and Environment. 2006;1:48-54.

[3] Zhang X, Kong F, Cao H, Tan J, Tao Y, Wang M. Recruitment dynamics of bloom-forming cyanobacteria in Meiliang Bay of Taihu Lake. The Journal of Applied Ecology. 2005;16:1346-1350.

[4] Kravchuk ES, Ivanova EA, Gladyshev MI. Spatial distribution of resting stages (akinetes) of the cyanobacteria Anabaena flos-aquae in sediments and its influence on pelagic populations. Marine and Freshwater Research. 2011;62:450-461.

[5] Tsujimura S, Tsukada H, Nakahara H, Nakajima T, Nishino M. Seasonal variations of Microcystis populations in sediments of Lake Biwa, Japan. Hydrobiologia. 2000;434:183-192.

[6] Beyruth Z. Periodic disturbances, trophic gradient and phytoplankton characteristics related to cyanobacterial growth in Guarapiranga Reservoir, Sao Paulo State, Brazil. Hydrobiologia. 2000;424:51-65.

[7] Hotto AM, Satchwell MF, Berry DL, Gobler CJ, Boyer GL. Spatial and temporal diversity of microcystins and microcystin-producing genotypes in Oneida Lake, NY. Harmful Algae. 2008;7:671-681.

[8] Kong F, Cao H, Tan X. Development of research on recruitment of bloom-forming cyanobacteria and blooms forecast. Environmental Monitoring and Forewarning. 2010;2:1-4.

[9] Schoene K, Jaenichen S, Ihle T, Ludwig F, Benndorf J. Arriving in better shape: Benthic Microcystis as inoculum for pelagic growth. Harmful Algae. 2010;9:494-503. [10]Verspagen JMH, Snelder E, Visser PM, Huisman J, Mur LR, Ibelings BW. Recruitment of benthic Microcystis (Cyanophyceae) to the water column: Internal buoyancy changes or resuspension? Journal of Phycology. 2004;40:260-270. 
[11] Brunberg AK, Nilsson E, Blomqvist P. Characteristics of oligotrophic hardwater lakes in a postglacial land-rise area in mid-Sweden. Freshwater Biology. 2002;47:1451-1462.

[12]Li K, Song L, Wan N. Studies on recruitment and growth characteristic of Microcystis in sediment. Acta Hydrobiologica Sinica. 2004;28:113-118.

[13]Reynolds CS, Jaworski GHM. Enumeration of natural Microcystis populations. British Phycological Journal. 1978;13:269-277.

[14]Tao Y, Kong F, Cao H, Zhang X. Simulative recruitment of Microcystis from the surface sediment in Taihu Lake. Scientia Limnologica Sinica. 2005;17:231-236.

[15]Brunberg AK, Blomqvist P. Benthic overwintering of Microcystis colonies under different environmental conditions. Journal of Plankton Research. 2002;24:1247-1252.

[16]Wan N, Tang J, Song L. Recruitment Mechanisms of Dormant Microcystis: A Review. Journal of Hydroecology. 2010;3:113-117.

[17]Zhou L, You W. Eutrophication characteristics of Shanzi Reservoir in Fujian province. Water Resources Protection. 2008;24:26-29.

[18]Zhang J-Z, Guo L, Fischer CJ. Abundance and Chemical Speciation of Phosphorus in Sediments of the Mackenzie River Delta, the Chukchi Sea and the Bering Sea: Importance of Detrital Apatite. Aquatic Geochemistry. 2010;16:353-371. [19]Ruban V, Lopez-Sanchez JF, Pardo P, Rauret G, Muntau H, Quevauviller P. Harmonized protocol and certified reference material for the determination of extractable contents of phosphorus in freshwater sediments - A synthesis of recent works. Fresenius Journal of Analytical Chemistry. 2001;370:224-228.

[20]Kim D-G, La H-J, Ahn C-Y, Park Y-H, Oh H-M. Harvest of Scenedesmus sp with bioflocculant and reuse of culture medium for subsequent high-density cultures. Bioresource Technology. 2011;102:3163-3168.

[21]Casamayor EO, Schafer H, Baneras L, Pedros-Alio C, Muyzer G. Identification of and spatio-temporal differences between microbial assemblages from two neighboring sulfurous lakes: Comparison by microscopy and denaturing gradient gel electrophoresis. Applied and Environmental Microbiology. 2000;66:499-508. 
[22]Rinta-Kanto JM, Ouellette AJA, Boyer GL, Twiss MR, Bridgeman TB, Wilhelm SW. Quantification of toxic Microcystis spp. during the 2003 and 2004 blooms in western Lake Erie using quantitative real-time PCR. Environ Sci Technol. 2005;39:4198-4205.

[23] Tillett D, Parker DL, Neilan BA. Detection of toxigenicity by a probe for the microcystin synthetase A gene (mcyA) of the cyanobacterial genus Microcystis, comparison of toxicities with 16S rRNA and phycocyanin operon (phycocyanin intergenic spacer) phylogenies. Applied and Environmental Microbiology. 2001;67:2810-2818.

[24] Te SH, Gin KYH. The dynamics of cyanobacteria and microcystin production in a tropical reservoir of Singapore. Harmful Algae. 2011;10:319-329.

[25]Nonneman D, Zimba PV. A PCR-based test to assess the potential for microcystin occurrence in channel catfish production ponds(1.2). Journal of Phycology. 2002;38:230-233.

[26]Neilan BA, Jacobs D, DelDot T, Blackall LL, Hawkins PR, Cox PT, Goodman AE. rRNA sequences and evolutionary relationships among toxic and nontoxic cyanobacteria of the genus Microcystis. Int J Syst Bacteriol. 1997;47:693-697.

[27]Marchesi JR, Sato T, Weightman AJ, Martin TA, Fry JC, Hiom SJ, Wade WG. Design and evaluation of useful bacterium-specific PCR primers that amplify genes coding for bacterial 16S rRNA. Appl Environ Microbiol. 1998;64:795-799.

[28] Stubner S. Enumeration of $16 \mathrm{~S}$ rDNA of Desulfotomaculum lineage 1 in rice field soil by real-time PCR with SybrGreen (TM) detection. Journal of Microbiological Methods. 2002;50:155-164.

[29]Cao H, Yang Z. Variation in colony size of Microcystis aeruginosa in an eutrophic lake during recruitment and bloom formation. Journal of Freshwater Ecology. 2010;25:331-335.

[30] Song X, Liu Z, Yang G, Chen Y. Effects of resuspension and eutrophication level on summer phytoplankton dynamics in two hypertrophic areas of Lake Taihu, China. Aquatic Ecology. 2010;44:41-54.

[31]Lurling M, Eshetu F, Faassen EJ, Kosten S, Huszar VLM. Comparison of 
cyanobacterial and green algal growth rates at different temperatures. Freshwater Biology. 2013;58:552-559.

[32]Post AF, Loogman JG, Mur LR. Regulation of growth and photosynthesis by Oscillatoria agardhii grown with a light/dark cycle. Fems Microbiology Ecology. 1985;31:97-102.

[33]Post AF, Dewit R, Mur LR. Interactions between temperature and light intensity on growth and photosynthesis of the cyanobacterium oscillatoria agardhii. Journal of Plankton Research. 1985;7:487-495.

[34]Cao H-S, Tao Y, Kong F-X, Yang Z. Relationship between temperature and cyanobacterial recruitment from sediments in laboratory and field studies. Journal of Freshwater Ecology. 2008;23:405-412.

[35] Yamamoto Y. Effect of temperature on recruitment of cyanobacteria from the sediment and bloom formation in a shallow pond. Plankton \& Benthos Research. 2009;4:95-103.

[36]Jia Y, Dan J, Zhang M, Kong F. Growth characteristics of algae during early stages of phytoplankton bloom in Lake Taihu, China. Journal of Environmental Sciences-China. 2013;25:254-261.

[37]Rossetti V, Schirrmeister BE, Bernasconi MV, Bagheri HC. The evolutionary path to terminal differentiation and division of labor in cyanobacteria. $\mathrm{J}$ Theor Biol. 2010;262:23-34.

[38]Zhao Q, Ren W. Advances on the researches of overwintering mechanism of cyanobacteria. Journal of Fudan University Natural Sciences. 2009;48:117-124.

[39]Wu X, Kong F, Zhang X, Zeng Q, Ji J, Qian S. Comparison of overwintering and rrecruitment of cyanobacteria in Taihu Lake and Chaohu Lake. Huanjing Kexue. 2008;29:1313-1318.

[40]Tan X. Comparison of benthic recruitment with pelagic growth of bloom-forming cyanobacteria. African Journal of Microbiology Research. 2012;6:3425-3430.

[41]Jin X, Chu Z, Yang B, Zheng S, Pang Y, Zeng Q. Effects of temperature on growth, photosynthesis and buoyancy regulation of the cyanobacteria Microcystis flos-aquae and Planktothrix mougeotii. Acta Scientiae Circumstantiae. 2008;28:50-55. 
[42] Tan X, Kong F, Yu Y, Sshi X, Zhang M. Effects of enhanced temperature on algae recruitment and phytoplankton community succession. China Environmental Science. 2009;29:578-582.

[43] Wan N, Tang J, Li L, Zheng L, Song L. Simulation on the sediments affecting Microcystis recruitment in north bay of Lake Dianchi. Hupo Kexue. 2009;21:806-812.

[44] Yamamoto Y. Contribution of bioturbation by the red swamp crayfish Procambarus clarkii to the recruitment of bloom-forming cyanobacteria from sediment. Journal of Limnology. 2010;69:102-111.

[45]Rengefors K, Gustafsson S, Stahl-Delbanco A. Factors regulating the recruitment of cyanobacterial and eukaryotic phytoplankton from littoral and profundal sediments. Aquatic Microbial Ecology. 2004;36:213-226.

[46] Yamamoto Y, Shiah F-K. Variation in the growth of Microcystis aeruginosa depending on colony size and position in colonies. Annales de Limnologie-International Journal of Limnology. 2010;46:47-52.

[47] Yamamoto $Y$, Tsukada H. Measurement of in situspecific growth rates of Microcystis (cyanobacteria) from the frequency of dividing cells. Journal of Phycology. 2009;45:1003-1009.

[48] Gervais F, Berger S, Schoenfelder I, Rusche R. Basic limnological characteristics of the shallow eutrophic lake Grimnitzsee (Brandenburg, Germany). Limnologica. 1999;29:105-119.

[49] Su Y, Zheng D, Lin W, Liang X, Huang N. Research of the characteristic of the seasonal thermal stratification in Shanzi Reservoir, Fujian Province. Journal of Fujian Normal University Natural Science. 2007;23:1-4,25.

[50]Kovacs AW, Toth VR, Voeroes L. Light-dependent germination and subsequent proliferation of $\mathrm{N}_{2}$-fixing cyanobacteria in a large shallow lake. Annales de Limnologie-International Journal of Limnology. 2012;48:177-185.

[51]Martins A, Moreira C, Vale M, Freitas M, Regueiras A, Antunes A, Vasconcelos V. Seasonal dynamics of Microcystis spp. and their toxigenicity as assessed by qPCR in a temperate reservoir. Marine Drugs. 2011;9:1715-1730. 
[52] Schirrmeister BE, Dalquen DA, Anisimova M, Bagheri HC. Gene copy number variation and its significance in cyanobacterial phylogeny. BMC Microbiol. 2012;12. [53] Oh KH, Jeong DH, Cho YC. Quantification of toxigenic Microcystis spp. in freshwaters by quantitative real-time PCR based on the microcystin synthetase A gene. Journal of Microbiology. 2013;51:18-24.

[54]Ostermaier V, Kurmayer R. Distribution and abundance of nontoxic mutants of cyanobacteria in lakes of the Alps. Microb Ecol. 2009;58:323-333.

[55]Bittencourt-Oliveira MD, Piccin-Santos V, Gouvea-Barros S. Microcystin-producing genotypes from cyanobacteria in Brazilian reservoirs. Environ Toxicol. 2012;27:461-471.

[56]Zhou Q, Chen W, Zhang H, Peng L, Liu L, Han Z, Wan N, Li L, Song L. A flow cytometer based protocol for quantitative analysis of bloom-forming cyanobacteria (Microcystis) in lake sediments. Journal of Environmental Sciences-China. 2012;24:1709-1716.

[57]Rhee J-S, Dahms H-U, Choi B-S, Lee J-S, Choi I-Y. Identification and analysis of whole microcystin synthetase genes from two Korean strains of the cyanobacterium Microcystis aeruginosa. Genes \& Genomics. 2012;34:435-439.

[58]Li Y, Li D. Competition between toxic Microcystis aeruginosa and nontoxic Microcystis wesenbergii with Anabaena PCC7120. Journal of Applied Phycology. 2012;24:69-78.

[59]Neilan BA. Identification and phylogenetic analysis of toxigenic cyanobacteria by multiplex randomly amplified polymorphic DNA PCR. Applied and Environmental Microbiology. 1995;61:2286-2291.

[60]Mikalsen B, Boison G, Skulberg OM, Fastner J, Davies W, Gabrielsen TM, Rudi K, Jakobsen KS. Natural variation in the microcystin synthetase operon mcyABC and impact on microcystin production in Microcystis strains. $\mathrm{J}$ Bacteriol. 2003;185:2774-2785.

[61]Foster RA, Kuypers MMM, Vagner T, Paerl RW, Musat N, Zehr JP. Nitrogen fixation and transfer in open ocean diatom-cyanobacterial symbioses. ISME J. 2011;5:1484-1493. 
[62]Karlson AML, Nascimento FJA, Suikkanen S, Elmgren R. Benthic fauna affects recruitment from sediments of the harmful cyanobacterium Nodularia spumigena. Harmful Algae. 2012;20:126-131. 
Table

Table 1. Determinants analysis of Microcystis and Oscillatoria recruitment from the sediment of Shanzi Reservoir.

\begin{tabular}{ccccccc}
\hline NO. & $\begin{array}{c}\text { Temperature } \\
\left({ }^{\circ} \mathrm{C}\right)\end{array}$ & $\begin{array}{c}\text { Light } \\
(\mathrm{lx})\end{array}$ & Disturbance & Nutrient & $\begin{array}{c}\text { Microcystis } \\
(\text { cells mL }\end{array}$ & $\begin{array}{c}\text { Oscillatoria } \\
\left(\text { cells mL }^{-1}\right)\end{array}$ \\
\hline 1 & 10 & 50 & - & Raw & $252 \pm 15$ & $252 \pm 10$ \\
2 & 10 & 50 & - & BG11 & $1,007 \pm 50$ & $168 \pm 8$ \\
3 & 10 & 2,000 & + & Raw & $2,768 \pm 138$ & $252 \pm 12$ \\
4 & 10 & 2,000 & + & BG11 & $1,258 \pm 58$ & $662 \pm 35$ \\
5 & 20 & 50 & + & Raw & $2,013 \pm 101$ & $1,258 \pm 50$ \\
6 & 20 & 50 & + & BG11 & $4,529 \pm 182$ & $1,258 \pm 65$ \\
7 & 20 & 2,000 & - & Raw & $9,934 \pm 397$ & $1,325 \pm 68$ \\
8 & 20 & 2,000 & - & BG11 & $7,285 \pm 219$ & $1,987 \pm 97$ \\
\hline$K_{1}(M .)^{*}$ & 1,321 & 1,950 & 630 & 3,742 & & \\
$K_{2}(M .)^{*}$ & 5,941 & 5,312 & 3,271 & 3,520 & & \\
$K_{1}(O .)^{*}$ & 334 & 734 & 933 & 772 & & \\
$K_{2}(O .)^{*}$ & 1,457 & 1,056 & 858 & 1,019 & & \\
\hline
\end{tabular}

* $K_{1}$ represents the experimental condition of $10^{\circ} \mathrm{C}, 50 \mathrm{~lx}$, no disturbance and raw water; $K_{2}$ represents the experimental condition of $20^{\circ} \mathrm{C}, 2,000 \mathrm{~lx}$, disturbance and BG11 medium. 
Table 2. Primers for total bacteria, cyanobacteria and Microcystis.

\begin{tabular}{|c|c|c|}
\hline Primer & Sequence (5'-3') & Reference \\
\hline mcyA_f & ATCCAGCAGTTGAGCAAGC & {$[23]$} \\
\hline mcyA_r & TGCAGATAACTCCGCAGTTG & {$[23]$} \\
\hline MCY_f1 & TGGGAAGATGTTCTTCAGGTATCCAA & {$[25]$} \\
\hline MCY_r1 & AGAGTGGAAACAATATGATAAGCTA & {$[25]$} \\
\hline MCY_r2 & GAGATCCATCTGTTGCAAGACATAG & {$[25]$} \\
\hline 16S_f1 & CGCAATGGGCGAAAGCCTGACGGAGC & {$[25]$} \\
\hline 16S_f2 & CCGCGTGAGGGAGGAAGGTCTTTG & {$[25]$} \\
\hline 16S_r1 & GCGTGCGTACTCCCCAGGCGGGATAC & {$[25]$} \\
\hline $209 f$ & ATGTGCCGCGAGGTGAAACCTAAT & {$[26]$} \\
\hline 409r & TTACAATCCAAAGACCTTCCTCCC & {$[26]$} \\
\hline $63 f$ & CAGGCCTAACACATGCAAGTC & {$[27]$} \\
\hline $1387 r$ & GGGCGGWGTGTACAAGGC & {$[27]$} \\
\hline $519 f$ & CAGCMGCCGCGGTAANWC & {$[28]$} \\
\hline $907 \mathbf{r}$ & CCGTCAATTCMTTTRAGTT & {$[28]$} \\
\hline
\end{tabular}

The primer pair 16S_f2/16S_r1 for Microcystis-specific 16S rRNA amplification; mcyA_f/mcyA_r for $m c y A$ microcystin synthetase gene amplification; MCY_f1/MCY_r2 for $m c y B$ microcystin synthetase gene amplification; 209f/409r for cyanobacteria-specific $16 \mathrm{~S}$ rRNA amplification; 63f/1387r for total bacteria $16 \mathrm{~S}$ rRNA amplification. For quantitative PCR program, the primers for Microcystis-specific 16S rRNA, mcyA microcystin synthetase gene, mcyB microcystin synthetase gene, cyanobacteria-specific $16 \mathrm{~S}$ rRNA and total bacteria 16S rRNA are 16S_f1/16S_r1, mcyA_f/mcyA_r, MCY_f1/MCY_r1, 209f/409r and 519f/907r, respectively. 
Table 3. Copies of $16 \mathrm{~S}$ and functional genes of total bacteria, cyanobacteria and Microcystis in the sediments of Shanzi Reservoir.

\begin{tabular}{lcccc}
\hline & Copies/(g dry sediment) & Efficiency & Slope & $\mathbf{r}^{2}$ \\
\hline Total bacteria 16S & $(4.4 \pm 0.03) \times 10^{9}$ & $106.00 \%$ & -3.186 & 0.9979 \\
Cyanobacteria 16S & $(3.6 \pm 0.31) \times 10^{6}$ & $98.15 \%$ & -3.367 & 0.9935 \\
Microcystis 16S & $(1.2 \pm 0.03) \times 10^{6}$ & $98.68 \%$ & -3.354 & 0.9908 \\
mcyA & $(2.1 \pm 0.14) \times 10^{5}$ & $102.26 \%$ & -3.269 & 0.9917 \\
$\boldsymbol{m c y B}$ & $(1.2 \pm 0.12) \times 10^{5}$ & $101.78 \%$ & -3.280 & 0.9979 \\
\hline
\end{tabular}

Note: The efficiency (between $90 \%$ and $110 \%$ ) and slope (between -3.58 and -3.10 ) were satisfied for the quantification of targeting $16 \mathrm{~S}$ and functional genes in environmental samples. 
Figure
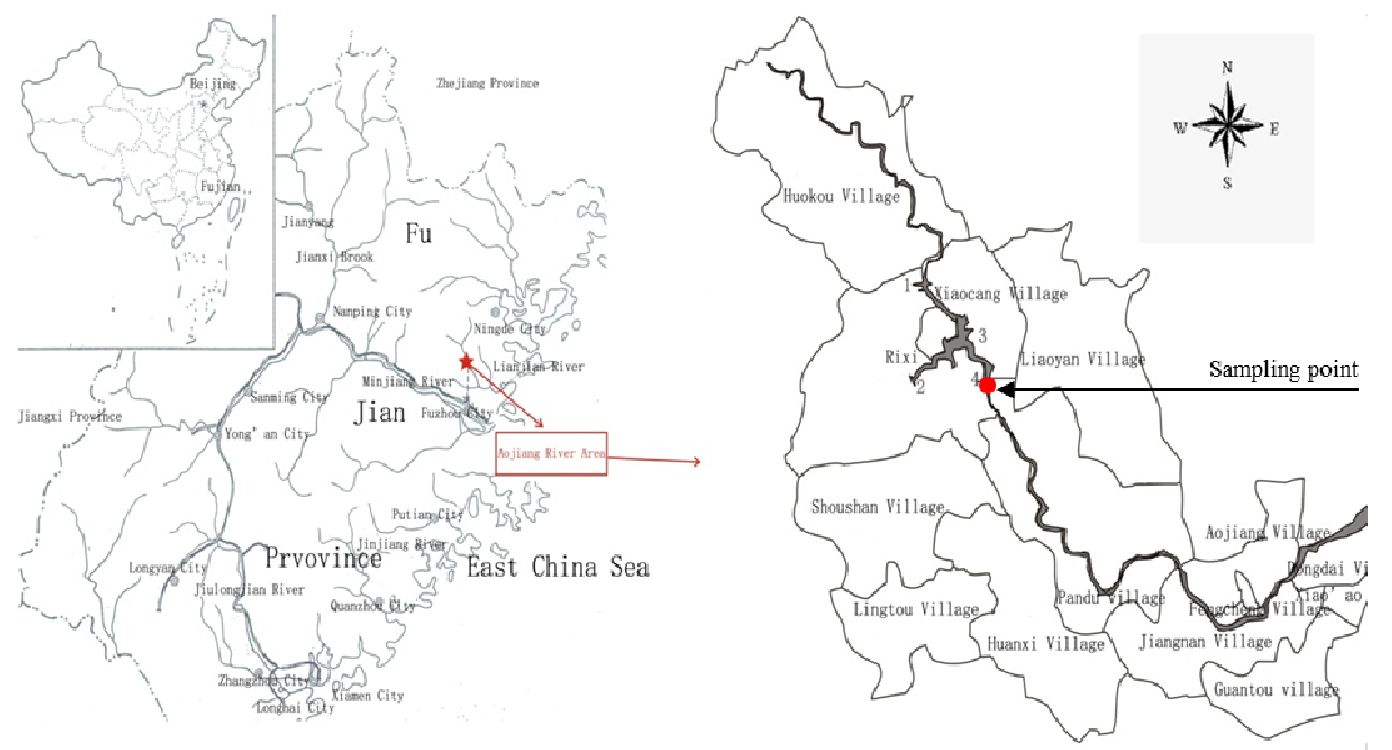

Figure 1. The location of Shanzi Reservoir and sampling point. 


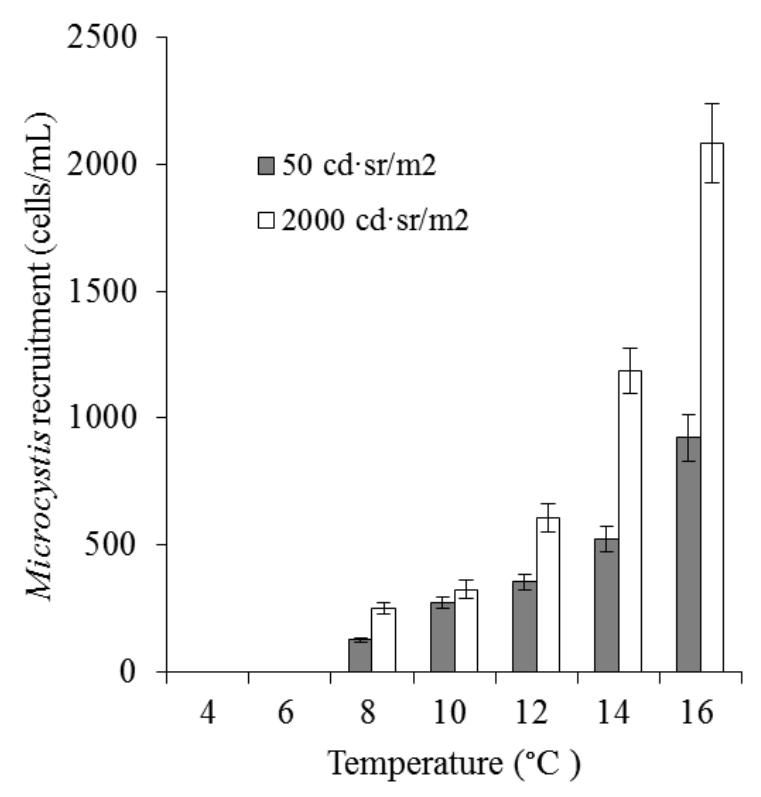

(a)

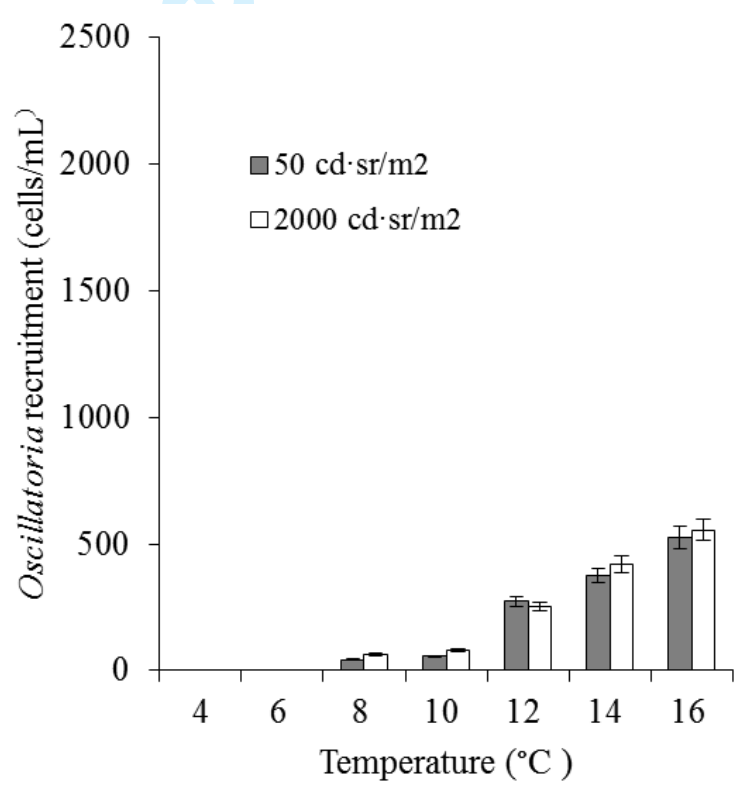

(b)

Figure 2. The recruitment of Microcystis (a) and Oscillatoria (b) from sediment samples of Shanzi Reservoir exposed to different temperature and light intensity. All the cyanobacteria were counted after 6 days cultivation in BG11 medium with a 12h:12h light-dark-cycle. The two treatments were of different light intensity during cultivation, $50 \mathrm{~lx}$ and 2,000 $\mathrm{cd}$ lx respectively. 


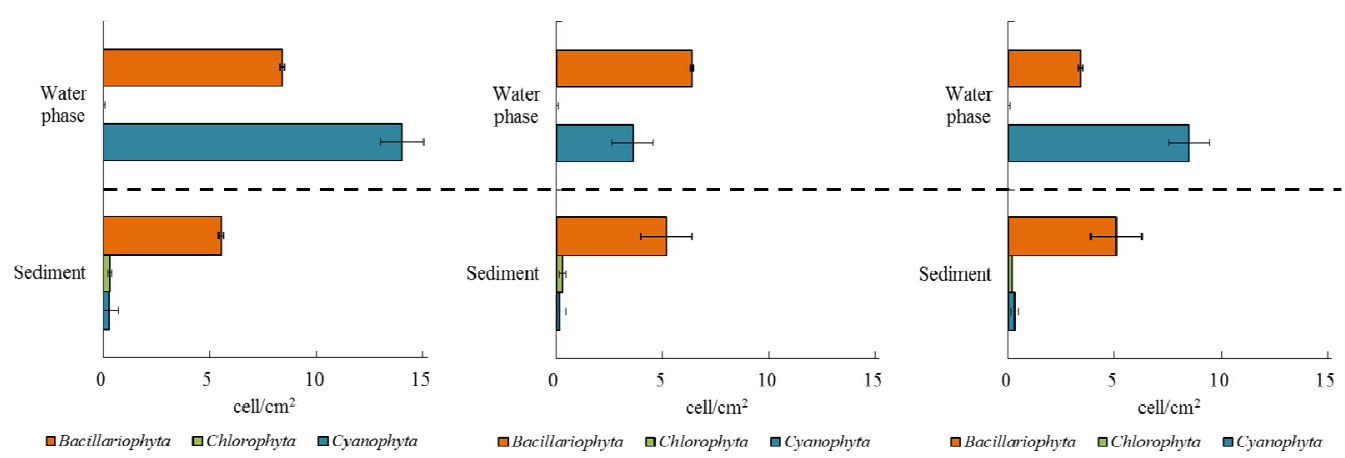

(a)

(b)

(c)

Figure 3. Cyanobacterial community structure at water-sediment interface: original sediment (a), $50 \mathrm{~lx}$ treatment (b) and 2,000 $\mathrm{lx}$ treatment (c). The cyanobacteria numbers inside the sediment and water phase were analyzed by microscope after recruitment. 


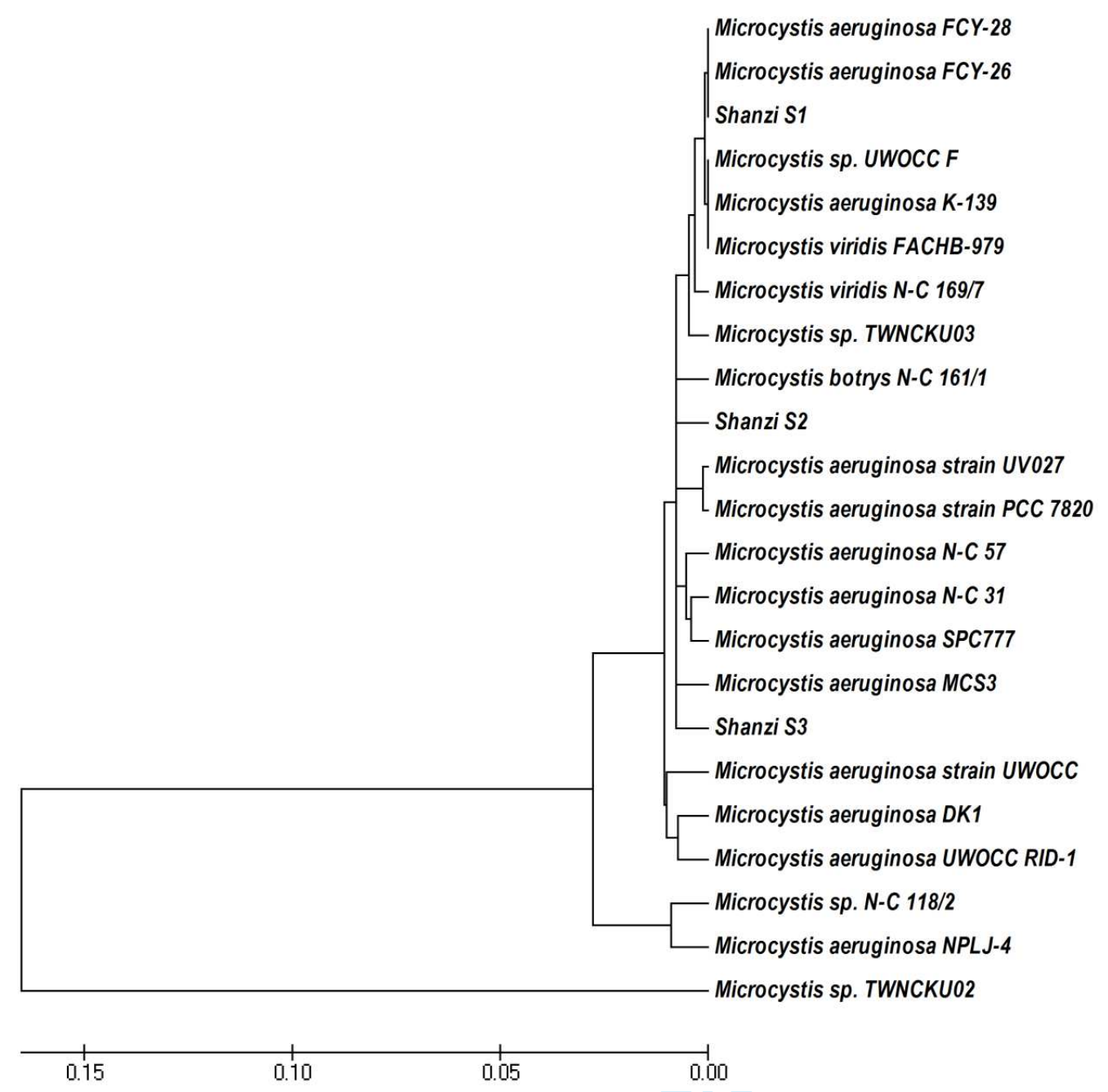

Figure 4. Phylogenetic analysis and Neighbour-Joining tree of Microcystis strains based on mycA gene. 


\section{Research on the recruitment of cyanobacteria from the sediment in the eutrophic Shanzi Reservoir}

Yuping $\mathrm{Su}^{1,2}$, Xuejing You ${ }^{1}$, Houzhang Zhong ${ }^{1}$, Hui $\mathrm{Li}^{1}$, Yanfang $\mathrm{Li}^{1}$, Ting Wang ${ }^{1}$, Dayi Zhang $^{2}$

1. Environmental Science and Engineering College, Fujian Normal University, Fuzhou, China PR, 350007.

2. Lancaster Environment Centre, Lancaster University, Lancaster, UK, LA1 4YW.

1. ANOVA analysis of Microcystis and Oscillatoria recruitment.

Table S1. ANOVA analysis of Microcystis.

\begin{tabular}{c|cccccc}
\hline & $\begin{array}{c}\text { SS } \\
\left(\times 10^{4}\right)\end{array}$ & $\mathrm{dF}$ & $\mathrm{MS}\left(\times 10^{4}\right)$ & $\mathrm{F}$ & $\mathrm{F} \alpha$ & Significance level \\
\hline Temperature & 4152.4 & 1 & 4152.4 & 435.2 & $\mathrm{~F} 0.05(1,1)=161.40$ & $*$ \\
Light (lx) & 2175.9 & 1 & 2175.9 & 228.0 & $\mathrm{~F} 0.01(1,1)=$ & \\
Physical & & & & & 4052.40 & $*$ \\
disturbance & 832.5 & 1 & 832.5 & 87.3 & & \\
Nutrients & 16.2 & 1 & 16.2 & 1.7 & & \\
Error e & 9.5 & 1 & 9.5 & & & \\
\hline
\end{tabular}

Table S2. ANOVA analysis of Oscillatoria.

\begin{tabular}{c|cccccc}
\hline & $\mathrm{SS}\left(\times 10^{4}\right)$ & $\mathrm{dF}$ & $\mathrm{MS}\left(\times 10^{4}\right)$ & $\mathrm{F}$ & $\mathrm{F} \alpha$ & Significance level \\
\hline Temperature & 252.4 & 1 & 252.4 & 198.6 & $\mathrm{~F} 0.05(1,2)=18.51$ & $* *$ \\
Light (lx) & 20.8 & 1 & 20.8 & 16.3 & $\mathrm{~F} 0.01(1,2)=98.50$ & \\
Physical disturbance & 1.1 & 1 & 1.1 & & & \\
Nutrients & 12.2 & 1 & 12.2 & 9.6 & & \\
Error e & 1.4 & 1 & 1.4 & & & \\
e $\Delta$ & 2.5 & 2 & 1.3 & & & \\
\hline
\end{tabular}

$\mathrm{SS}=$ sum of squares of deviations; $\mathrm{dF}=$ degrees of freedom variance; $\mathrm{MS}=$ mean square;

$* *=$ Significantly correlated; Round-off error e $\Delta$. 
2. Calibration curve of quantitative PCR

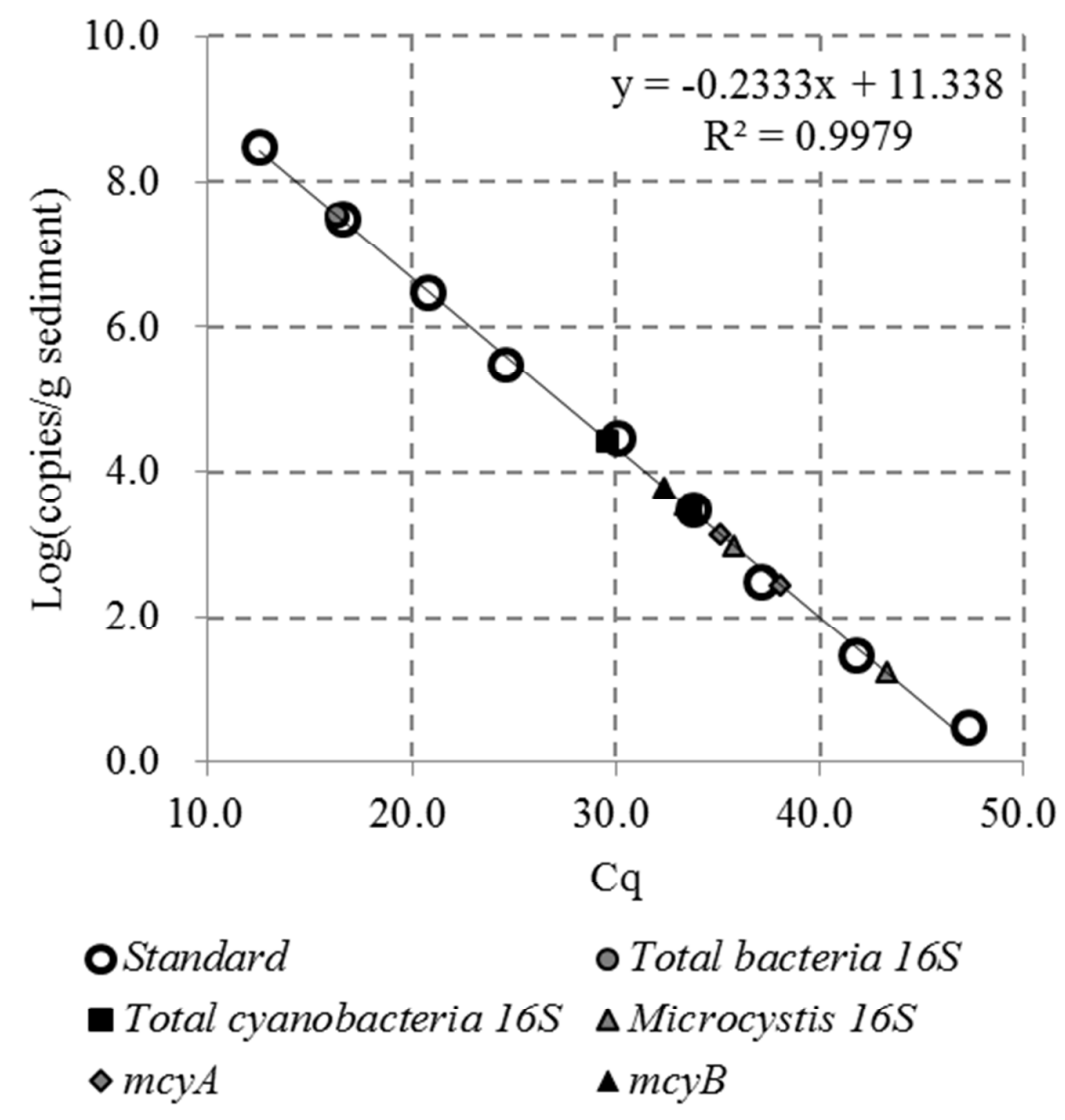

Figure S1. Calibration curve for quantitative PCR. 